I Universidade de São Paulo (USP), Departamento de Antropologia, São

Paulo, SP, Brasil

vagnergo@usp.br

https://orcid.org/0000-0002-I253-568I

Vagner Gonçalves da Silva'

\title{
MEMÓRIAS E EXPERIÊNCIAS DE PESQUISA NA CASA DAS MINAS DE SÃO LUÍS DO MARANHÃO: ENTREVISTA COM SERGIO FERRETTI
}

Em 27 de julho de I995, em meio à pesquisa de doutorado que desenvolvi sobre o trabalho de campo e a produção de textos etnográficos na área dos estudos sobre as religiões afro-brasileiras no Programa de Pós-Graduação em Antropologia Social da Universidade de São Paulo (Silva, 2005), entrevistei Sergio Figueiredo Ferretti, cujos trabalhos sobre a Casa das Minas de São Luís do Maranhão (Ferretti, I995; I985) se destacam no panorama desses estudos. A entrevista foi realizada em sua residência naquela mesma cidade e integrou a pesquisa que enfocou a experiência dos antropólogos pesquisadores e dos religiosos cujos terreiros foram etnografados em diversas cidades do Brasil. Todas as entrevistas foram gravadas e, após transcritas, submetidas aos entrevistados para que sugerissem alterações, acréscimos ou supressões e para que seu uso fosse autorizado. Trechos dessas entrevistas foram publicados no livro O antropólogo e sua magia (Silva, 2000). A entrevista de Ferretti é aqui publicada com notas que visam contextualizar as informações fornecidas.

Vagner Gonçalves da Silva. Como ocorreu seu interesse pela área dos estudos das religiões afro-brasileiras?

Sergio Ferretti. Eu tinha um interesse especial por religião, pois fui monge beneditino. Mas uma parte da minha família era espírita, e a outra era católica. Eu tinha uns problemas de religião mal resolvidos. Então, chegando ao Maranhão, descobri as religiões afro-brasileiras. Inicialmente resolvi fazer um projeto de pesquisa sobre cultura popular. O livro de Roger Bastide tinha acabado 
de ser publicado no Brasil, em português - isto conto em minha tese de mestrado -, o qual eu tinha estudado na Europa, num curso muito interessante que fiz sobre contato das civilizações. Eu não tinha o livro lá. Li na biblioteca. Aqui pude ter acesso ao livro, consultei com mais vagar e vi que ele falava sobre a área religiosa do Maranhão e me interessei por conhecê-la. Seguindo esse caminho de Roger Bastide bati direto na Casa das Minas. E por ali fiquei com aquela curiosidade e procurei desencavar um pouco a bibliografia. No começo, apesar de me interessar vivamente por estudar esse assunto, tive muita dificuldade para entrar na Casa das Minas; foi muito lento esse contato. Interessei-me por esse assunto em 1972 e terminei minha dissertação de mestrado em I983.

V.G.S. Quando você veio para o Maranhão?

S.F. Vim em I963 para trabalhar num movimento de educação de base e fiquei um tempo aqui. Era recém-formado, ligado à ação católica na universidade, e tive um convite para trabalhar na área de igreja. Nesse ano conheci Mundicarmo. Depois fui embora para a Europa. Fiz um curso lá e voltei em I967. Casei em I968 e vim de vez para o Maranhão em I969. Em I972 fui fazer um projeto de pesquisa sobre cultura maranhense e reli o Bastide. Mas, eu tive dificuldade de ter acesso à Casa das Minas, porque é um ambiente muito fechado. Demorei muito tempo, uns três ou quatro anos, para encontrar o livro do Octávio da Costa Eduardo. Procurei no Brasil inteiro, só achei no Museu Goeldi - isso eu conto na dissertação de mestrado. O que não conto é que eu queria entrar na Casa das Minas e queria ter um pretexto porque eu não conhecia ninguém lá. Cheguei lá num dia de festa de Santa Bárbara. Devia ser I972. Entrei e escutei umas pessoas cantando naquela sala onde tem o altar. Entrei, olhei e fiquei olhando, e era um bando de mulheres velhas, muito brancas, como fantasmas. Eram os voduns. Eu tive impressão que era por ser tão velhas que eram brancas. Curvadas. Fiquei morrendo de medo, aterrorizado. Olhei fixamente, e um vodum me olhou com muita fixação nos olhos com aquela tranquilidade dos voduns. Cheguei na porta, parei um pouquinho, olhei e saí [risadas], tamanho foi o impacto. Agora, eu mordi a isca [risadas]. Eu fiquei curiosíssimo para conseguir entrar lá. Eu trabalhava num museu histórico e nessa época, I973, a primeira-dama resolveu fazer mais um museu. Tinha sido criado um museu em I973, mas ela ia sair e queria abrir outro, porque deu muito prestígio inaugurar um museu. Então, resolveu fazer a Cafua da Mercês. E para fazer a Cafua ela precisava de alguém que fosse procurar algumas peças relacionadas com a cultura negra. E a mesma museóloga que veio aqui organizar o museu no qual eu trabalhava desde o início - que eu também sou museólogo - veio para organizar a Cafua. Arlete Machado estava na Secretaria de Cultura. Ela é uma intelectual e tem muita penetração na área de cultura. Ela soube que a Casa das Minas estava precisando de uma ajuda material para reforma. A Casa de Nagô tinha 
recebido uma ajuda algum tempo antes, e a Casa das Minas não tinha recebido, e um pedaço dela estava desabando. Como a Cafua também estava desabando, a Arlete falou com a primeira-dama para a restaurarem. Arlete me chamou e fomos - a primeira-dama, dona Enei Santana, Arlete e eu - à Casa das Minas. Pela primeira vez entrei oficialmente na Casa das Minas. Fiquei com tanto medo, que não voltei lá. Fiquei lendo, procurando coisas. A partir daí, em troca de uma ajuda que foi dada pelo governo à Casa das Minas, se conseguiram umas peças para o Museu e passei a voltar lá para pedir informações sobre aquelas peças. Comecei a conversar com dona Amância, que era a chefe da Casa. Fiquei uns dois anos conversando com ela. Ia quase toda semana. Me tornei seu amigo. Ela morreu em I976, e até esse ano eu só conversava com ela na Casa das Minas. Eu entrava lá, falava apenas "bom dia" ou "boa tarde" para os demais. [...] E ninguém falava comigo. Entrava, conversava com ela e com familiares dela também, e assistia às festas.

V.G.S. Por quê?

S.F. Eu sou meio tímido e não era ainda um antropólogo também. Não tinha muita facilidade. Minha formação foi em história e museologia, e embora eu desse aula de antropologia, não tinha uma formação específica para fazer uma pesquisa antropológica. Perdi muito tempo no começo. No dia em que ela morreu, dona Celeste veio conversar comigo. Foi a primeira vez que conversei com outra pessoa além da chefe da Casa.

V.G.S. Você gravava as conversas com ela?

S.F. Não. Eu anotava.

V.G.S. Anotava na frente dela?

S.F. Na frente dela. Eu fazia fichas e anotava. Ainda tenho essas anotações. E assistia às festas e colaborava com elas também.

V.G.S. E ela não perguntava a razão de seu interesse?

S.F. Eu falava de meu interesse em fazer um estudo sobre a Casa. Mas isso demorou muito tempo. Primeiro, porque eu não tinha um projeto pronto, não tinha feito um curso de mestrado ainda. Depois, eu tinha outras atividades. Coordenei uma pesquisa pequena sobre a dança do lelê na Secretaria de Cultura (Ferretti et al., I977) e treinei uma equipe, e daí resolvemos fazer uma pesquisa mais ampla, que durou quase um ano (Ferretti et al., I978). Estudamos a literatura com uma equipe maior. Tivemos um treinamento. Eu pensava em fazer uma pesquisa sobre o tambor de mina, mas 
fui aconselhado pelo presidente da Fundação Cultural, o folclorista Domingos Vieira Filho, a fazer uma pesquisa menor e mais viável sobre tambor de crioula, pois ele considerava o tambor de mina muito mais complicado. E nós fizemos (Ferretti et al., I98I), mas já nessa pesquisa eu escrevi um capítulo sobre a relação do tambor de crioula com o tambor de mina. Para isso, entrevistei dona Elzita, dona Celeste (dona Amância já tinha morrido) e Jorge que eu conheci Jorge em 1972. Por ocasião da passagem do sociólogo suíço Jean Ziegler pelo Maranhão, o reitor da universidade, que estava viajando, pediu-me para recebê-lo, pois eu falava bem o francês. Levei-o ao terreiro de Jorge, pois a Secretaria de Turismo do Município me havia informado que a mãe dele havia organizado um tambor de choro lá. Jean Ziegler achou muito interessante e até escreveu um artigo no livro Os vivos e os mortos (Ziegler, 1977). Depois disso Jorge também me chamou para algumas cerimônias semiprivadas na casa dele. Ele me considera muito amigo porque fui um dos primeiros intelectuais do Maranhão que levou outras pessoas lá. Eu também dava aulas de antropologia sobre negro e tive contato com algumas pessoas, como Rosário Carvalho e com Lalá [Eladir Pereira] da Casa de Nagô, que foram minhas alunas. Lalá era muito amiga de Euclides e foi quem me levou à Casa de Fanti-Achanti. Com isso eu entrei um pouco na rede da Casa das Minas, Casa de Nagô, Casa do Jorge e Casa de Fanti-Achanti, mais ou menos ao mesmo tempo. Mas o meu interesse era a Casa das Minas por influência de Bastide, inegavelmente.

V.G.S. Você já tinha em mente que ia fazer uma tese?

S.F. Logo no começo pensei em fazer um mestrado sobre a Casa das Minas. Mas naquela época era complicado. Estava com filho pequeno e não tinha programa de mestrado no Maranhão. Teria que ser no Rio de Janeiro ou em São Paulo, e eu teria de me deslocar para qualquer dessas duas cidades. Em I978, foi criado o mestrado no Rio Grande do Norte. Eu tinha pensado em fazer o mestrado em Salvador ou em Recife, onde conhecia Roberto Mota. Mas na época surgiu o mestrado do Rio Grande do Norte com boas expectativas e professores que tinham se formado no Programa do Museu Nacional, da Universidade Federal do Rio de Janeiro. Estava sendo implementado por uma ex-colega minha no curso de sociologia da Universidade de Louvain na Bélgica. E a família de minha mulher é do Rio Grande do Norte, então tínhamos familiares lá. Meu filho estava no curso primário. Então, nos deslocarmos para lá era uma coisa relativamente fácil. Mas só em 1978 conseguimos. Fiz o mestrado já com a intenção de fazer uma tese sobre a Casa das Minas. No decorrer do curso conheci o professor Kabengele Munanga, e o escolhi como orientador. $\mathrm{Na}$ disciplina "Métodos e técnicas de pesquisa" fiz o projeto de pesquisa que resultou no Querebentã de Zomadonu.

V.G.S. Quando você conversava com o pessoal da Casa das Minas a sua ideia era fazer uma etnografia. Você tinha alguma hipótese? 
S.F. Não. Eu sou muito etnográfico [risadas]. Até hoje eu trabalho muito com etnografia.

V.G.S. Você tinha um roteiro ou conversava sobre todos os assuntos?

S.F. Não tinha. Aí ocorreu um problema. Hubert Fichte, que era um grande entrevistador, chegou ao Maranhão. Ele tinha entrevistado condenado à morte, presidente da República, Jean Genet, grandes personagens. Era um grande escritor e um grande entrevistador. Quando voltei a São Luís em março, pois já tinha cumprido os créditos, comecei a arrumar as coisas, o projeto, a rever bibliografia e saí de férias antes de começar de fato. Quando ele chegou em São Luís, eu já estava trabalhando há uns três meses na pesquisa. Fiquei um tanto preocupado. Ele gostou tanto, que resolveu ficar trabalhando oito meses no Maranhão. E nós trabalhamos muito juntos! Eu já tinha o meu projeto, e justamente desenvolvemos muito a técnica de entrevista; ele me ajudou muito. Conversamos longamente e durante muito tempo com dona Deni e com dona Celeste. Foi com esse material que fiz a minha dissertação de mestrado, que é uma etnografia da Casa das Minas.

V.G.S. Como era esse processo de trabalho?

S.F. Primeiro, eu queria comparar a Casa das Minas com a Casa de Nagô. Iria estudar religião e desenvolvimento, religião e mudança. Queria estudar uma casa tradicional e uma casa moderna. Depois de três ou quatro meses vi que era meio complicado. Comecei a trabalhar com Euclides, na Casa de Nagô, e com a Casa das Minas. Mas no segundo semestre resolvi ficar só na Casa das Minas. Comecei a entrevistar dona Celeste, as pessoas mais próximas e também um pouco aqueles a quem conhecia. Conversava bastante com Fichte. Apresentei meu projeto a ele. Ele achou interessante e deu até algumas sugestões. Ele não era antropólogo, era escritor. Semanalmente, às quartas-feiras, mais ou menos de três e meia até as sete da noite, marcávamos os dois uma conversa com a dona Deni, então a chefe da Casa. Uns 40 minutos antes nos encontrávamos e planejávamos a conversava daquele dia. Não era gravada. Anotávamos. Cada um levava o seu caderno e anotava.

V.G.S. Por que não era gravada? Ela não deixava?

S.F. Eu não gosto de trabalhar com gravador, nem ele. Eu já trabalhei algumas vezes com gravador. Mas acho que inibe a pessoa, sobretudo nessa área de religião, com pessoa do povo. Então, fazíamos um roteiro de conversa, e um ia sustentando o interesse do outro. Quando a conversa caía, tentávamos animá-la e não atrapalhar. Depois voltávamos para nossas respectivas casas e ficávamos mais de uma hora ao telefone, discutindo o que se passara. Conversávamos semanalmente também com dona Celeste, durante umas duas horas. E ele, pessoalmente, resolveu dar um 
curso de francês para dona Deni para que ela pudesse fazer uma viagem à África, um projeto dele. Ele coletou dados sobre a história de vida dela que aparece num capítulo do livro Etnopoesia. Ao mesmo tempo, ele tinha vontade de escrever uma peça de teatro sobre as intrigas das velhas da Casa das Minas, como uma peça de teatro grego. Ele anotava nos cadernos e em papeizinhos as ideias que guardava em duas caixas de sapato; fazia umas quatro ou cinco mil fichas e depois guardava tudo no fichário remetendo aos cadernos. Ele contava que, quando acabava de fazer um livro, rasgava a ficha, o fichário, e jogava tudo fora. Eu guardei o meu fichário. Tenho umas quatro mil fichas, mais ou menos. Tenho fichário de assuntos, de nomes próprios e um de cânticos da Casa das Minas. Por exemplo, o tambor de choro. Toda vez que aparecia tambor de choro no meu caderno, que era numerado (tenho uns oito cadernos), e cujas páginas eram também numeradas eu fazia um índice que me remetia também às fichas. Essa metodologia - que ele, como alemão, havia aprendido - me foi muito útil para arrumar aquele acúmulo de dados na minha cabeça. Mundicarmo trabalhava muito com as margens dos cadernos. Eu, às vezes, puxava as palavras-chave para as margens. Eu tenho uma letra difícil, muito ruim, mas eu tentava. Esses fichários são úteis até hoje. Trabalhei longamente com essas fichas na minha dissertação de mestrado.

V.G.S. Qual era o interesse do Fichte? Era diferente do seu?

S.F. O Fichte era um escritor. O livro dele sobre a Casa das Minas, que o Andreas Hofbauer leu para nós, pois não leio alemão, tem muitas coisas parecidas com o meu livro, porque foram colhidas juntas, mas ele talvez quisesse narrar uma história de um povo exótico, de um povo estranho. Ele era talvez um pouco evolucionista ou historicista daquela escola alemã. Porém fizemos o trabalho de campo juntos durante oito meses. Quando ele voltou para a Alemanha, havíamos terminado. Eu fiquei redigindo a minha etnografia com minhas ideias e com outra construção. $\mathrm{O}$ livro de Ficht tem muitas coisas parecidas, muitas palavras iguais às minhas, mas são dois livros com estruturas e arrumação completamente diferentes. No começo fiquei meio desconfiado, mas foi muito bom. Ele me ajudou muito, e acho que o ajudei. Seu livro póstumo sobre a Casa das Minas indica "com a colaboração de Sergio Ferretti". Também nos outros trabalhos que ele escreveu sobre a Casa das Minas ele me cita muito. A viúva dele me enviou um livro chamado Explosão em que fala muito de dona Celeste, de Sergio Ferretti [risadas]. Mas trabalhávamos de forma e com enfoque diferentes. Eu já tinha uma metodologia desenvolvida na academia e procurei fazer uma etnografia que mostrasse a estrutura e o funcionamento da Casa, as divindades, o panteão, a estrutura dos rituais.

V.G.S. A Casa das Minas é extremamente fechada...

S.F. Muito fechada. Por isso demorei tanto tempo: dez anos para acabar a pesquisa de mestrado e quase 20 a de doutorado. 
V.G.S. Quando você começou a fazer essas entrevistas mais sistemáticas, você também aproveitou aqueles dados anteriores?

S.F. Claro. Esses dados me foram muito úteis porque eram justamente sobre a mitologia. Eu conversei muito sobre mitologia com dona Amância, e o esquema que tenho da mitologia da Casa até hoje me foi dado por ela. Agora, pode ser até que haja dúvidas nesse esquema: se fulano é filho de sicrano. Dona Amância tinha entrado na Casa em I905, mais ou menos. Era a pessoa mais antiga da Casa; mais antiga até do que dona Amélia. Ela conhecia bastante a mitologia da Casa. Elaborei a estrutura das famílias dos voduns com base nas informações básicas dadas por ela.

V.G.S. Dona Amância já havia falecido quando você e Fichte passaram a fazer entrevistas?

S.F. Sim, ela faleceu em I976. Comecei o mestrado em I978. Entrevistei as pessoas com Fichte em I98I.

V.G.S. Suas conversas no período da pesquisa de mestrado eram mais com dona Deni e com dona Celeste?

S.F. Depois de dona Amância, passei a conversar muito com dona Celeste, que gosta muito da festa do divino. Então, com ela conversava sobretudo sobre a festa do divino e com ela comecei a me entrosar mais abertamente na Casa. Dona Celeste é muito democrática. Com dona Amância eu fui padrinho de uma caixa do divino e frequentava as festas públicas principais. Mas com dona Celeste frequentava todas as festas e me tornei mais íntimo das pessoas. Agora, com dona Deni e com Fichte, entramos mais no âmago. Porque dona Deni é a detentora do conhecimento da Casa. Ela é como se fosse Ogontemmêli. Ela de fato é a intelectual da Casa. E eu tinha um certo receio. Até hoje tenho uma certa dificuldade de me aproximar dela. Um pouco por conta da hierarquia, daquele negócio da chefia. Ela praticamente é a chefe da Casa. Dona Celeste, não; com ela tenho uma relação muito mais íntima.

V.G.S. Por que elas abriram tanto assim o acesso para você? A que você atribui isso?

S.F. Primeiro, acho que elas não abriram tanto. Estou lá há 20 anos, mas nunca entrei no peji, por exemplo. E nem pretendo entrar. E nunca pedi para entrar.

V.G.S. Se você pedisse, seria negado?

S.F. Claro. Eu nunca pedirei. Pode ser até que um dia eu entre, não sei. Acho que não. Não tenho nem pretensão. 
V.G.S. Só entra quem é da casa?

S.F. Não. Nunes Pereira entrou. Ele conta em seu livro. Ele não diz explicitamente, mas percebe-se que ele entrou.

V.G.S. Por que você acha que isso se deu com ele?

S.F. Ele era filho da casa. Mãe Andresa o conheceu como criança. As crianças às vezes entravam... Ele não conta se entrou quando criança ou já adulto. Talvez ele tenha entrado quando criança e na fase adulta ele não tenha entrado mais.

V.G.S. O fato de ser homem ou mulher interfere? Os tocadores entram?

S.F. O huntó chefe entra. Os tocadores preparados entram e participam das matanças. São eles que fazem a matança dos animais de quatro patas lá dentro. Agora, o fato de ser homem ou mulher é muito diferente. Se eu fosse mulher, teria mais facilidade de acesso para certas coisas.

V.G.S. A Mundicarmo, que está começando agora um contato de pesquisa, tem outro tipo de inserção?

S.F. Claro; mulher tem muito mais facilidade porque é uma casa de mulher. Se eu fosse mulher teria entrado com muito mais facilidade. Mundicarmo tem todo um outro jeito, outra facilidade de relacionamento. Eu tenho, às vezes, uma facilidade exterior de me aproximar, mas interiormente sou muito mais difícil de relacionamento. Sou um antropólogo com muita dificuldade de me comunicar. É uma das maiores dificuldades, porque antropólogo tem que ter essa facilidade de comunicação com o outro, sobretudo com os mais simples. Eu sou muito inibido.

V.G.S. Mas de qualquer maneira elas abriram bastante o acesso para você.

S.F. Justamente com Fichte, que era muito furão. Eu fui junto com ele. Ele forçou talvez um pouco a barra, e eu fui junto. Por exemplo, nós ganhamos um cargo juntos na Casa. Somos irmãos de iniciação na Casa, somos filhos da Casa, somos assissi, somos como se fôssemos ogãs, entende? Temos colar de contas, que é muito mais de que um colar de contas lavado no candomblé. E nos foram dados juntos.

V.G.S. E isso foi na época das entrevistas?

S.F. Foi no fim das entrevistas. Na penúltima parte. 
V.G.S. Você acha que isso ajudou?

S.F. Ajudou muito, porque com esse colar, essa guia, sou uma pessoa da Casa. Qualquer problema que tenha, sou de dentro do grupo. Euclides tinha me convidado para ser ogã da sua Casa, mas nunca aceitei. Quando dona Deni leu isso no livro que ele escreveu, ela me disse: "Ah, mas não se pode servir a dois senhores, você não pode ter duas casas. De jeito nenhum. Ou uma coisa ou outra". Eu lhe disse: "Não, ele quer que eu seja ogã, mas não sou ogã da casa dele. Ele colocou que sou ogã porque é um desejo dele, mas não sou. Me convidou, mas nunca aceitei e não tive relação nem nada". A partir daí afastei-me um pouco de Euclides. E Hubert Fichte nos oito meses que passou aqui em São Luís nunca foi a outro terreiro a não ser a Casa das Minas. Ele conversava com mãe Dudu da Casa de Nagô, e apenas já nas vésperas de ir embora, ele foi à Casa de Euclides.

V.G.S. Imagino que você tenha recebido esse colar devido a sua longa convivência, mas como explicar o colar dado a Fichte, que era estrangeiro e de repente foi aceito?

S.F. Ele foi aceito e era adorado lá. Ele era uma pessoa simpaticíssima, daquelas que todo mundo ama, que cativa todo mundo. Então, ele presenteava as pessoas e tinha muito carisma. Ele trouxe uns presentes africanos que elas até não gostaram, mas ele trouxe uma conta igual à conta do rosário de mãe Andresa. Quando ele mostrou aquela conta, o pessoal ficou impressionado. Ele propôs dar aquela conta para dona Deni e que ela, em troca, colocasse no rosário dele a conta do rosário de mãe Andresa. O senhor dele era o senhor de mãe Andresa. Ele gostava muito da religião, de ver, ouvir, sabia entrar, entende? E essa conta foi uma coisa marcante, tanto que ele levou uma missão daqui. Ele saiu com uma carta da Casa das Minas para um descendente do rei do antigo Daomé, o atual Benim. Ele foi como um embaixador da Casa das Minas [...]. Quando ele morreu, a viúva veio trazer a guia dele de volta para a Casa, porque, quando a pessoa morre, a guia tem que voltar. E ninguém pode tocar com a mão na guia, só a própria pessoa e a chefe da Casa que lidava com ela. Quando a guia foi devolvida justamente eles a reconheceram.

V.G.S. As pessoas da Casa das Minas leem a sua etnografia?

S.F. Leem. Eu faço questão; assim que sai o livro, dou um para cada um. Inclusive antes peço aos voduns que me ajudem a publicá-lo. Eu levo muitas velas, muitas luzes para o livro ser publicado. Eu entreguei a dissertação de mestrado e de doutorado para várias pessoas. A de doutorado nem tanto, pois eu tinha poucas cópias e esperava que o livro fosse sair logo. Quando o livro foi publicado, fiquei muito sem jeito por conta da capa que é vermelha e preto e custei uma semana para entregar a elas. Quando entreguei, elas disseram: “Mas podia ser azul”. Eu havia dito, quando entreguei na editora a pesquisa para publicação em livro, que a única coisa 
que não poderia ter na capa era a cor preta! E eles fizeram na cor preta [risadas]. $\mathrm{O}$ artista que fez a capa não sabia disso. Mas elas não criaram nenhum problema porque, inclusive misteriosamente, o nome da Casa das Minas não aparece na capa, nem na folha de rosto. Estranhamente, o que é um erro. Aparece só na ficha catalográfica. Felizmente. Entreguei para dona Deni e ela me disse que está lendo e tem várias coisas erradas. Pedi para que ela lesse com atenção e disse-lhe que logo queria estar com ela. Ela disse que, às vezes, não sou muito atento e que preciso ser mais atento [risadas], saber escutar, acompanhar e não falar coisas erradas.

\section{V.G.S. Mas não coisas secretas?}

S.F. Isso eu não sei. Ela não falou sobre coisas secretas. Eu é que perguntei muito... Essas coisas aparecem na parte dos cânticos de que falo muito pouco por ser muito complicada. Exige conhecimento de etnolinguística, de etnomusicologia. Eu não me atrevi. Inclusive ela me dizia que os cânticos são dos voduns. Mas agora tenho impressão de que ela está querendo que eu seja um pouco o escritor dos cânticos para a casa. Estou disposto a seguir esse conselho. Continuo muito ligado a ela.

V.G.S. Elas também leram Querebentã e fizeram algum tipo de avaliação?

S.F. Algumas pessoas fizeram algumas críticas de detalhes: "Ah, tal dado está errado, tal nome está errado". A letra de Querebentã é muito horrível, e elas enxergam muito mal. Se fosse o livro de Mundicarmo, com letras grandes, elas teriam lido. Elas comentaram alguns erros, pois sempre encontram erros de detalhes etnográficos.

V.G.S. E com relação ao segredo?

S.F. Eu não conto nada de segredo da Casa das Minas. Eu falo de segredo: alguns nomes dos voduns e algumas dijinas. São coisas mais discretas. O que envolve segredo são os cânticos. Isso não é uma coisa que todo mundo sabe ou fale. Os nomes dos voduns são... não se diz o santo nome de Deus em vão... Eu digo alguns nomes de alguns voduns, mas os voduns têm vários nomes. Nunca me foi dito que isso é um segredo. Às vezes, um nome emerge nas toadas, nos cânticos. Eu transcrevi alguns nomes. Agora, algumas coisas eu interpretei. Tenho impressão de que são as interpretações que fiz que elas consideram erradas. Estou curiosíssimo para saber o quê. Inclusive estou disposto a ler o livro inteirinho para elas, para poderem corrigir [risadas].

V.G.S. E fazer outra edição?

S.F. E fazer outra versão. Realmente vai ser muito mais interessante. Em relação às toadas não sei como vai ser. Se eu tiver mais acesso a esses cânticos... Por exemplo, o Octávio da Costa Eduardo se comprometeu a não publicar em português o livro dele. 
V.G.S. Você sabe como foi a relação do Octávio com elas para conseguir as informações?

S.F. Eu já conversei muitas vezes com ele, que é apaixonado pela Casa das Minas. Ele começa a chorar quando fala. Fica muito emocionado. O pessoal antigo fala muito bem dele aqui e em Codó. Mas ele fez a pesquisa em I944, era um jovem de 24 anos, e a última vez que eu o vi ele estava com 70 anos. Ele se aproximou muito da Casa Chegou numa época em que tinha muita gente importante na Casa, que conhecia bem a coisa, e ele pegou dados interessantes. Mas ele entrou naquela fôrma do culturalismo. Ele me disse que tinha muito mais material, mas que tinha pressa de acabar o trabalho e voltar dos Estados Unidos.

V.G.S. Sobre a sua participação como religioso na Casa das Minas, elas te cobram de cumprir funções religiosas?

S.F. Elas cobram muito pouco na Casa das Minas, entende?

V.G.S. Pelo fato de ser homem?

S.F. Não, não. Eu espontaneamente dou ajuda financeira para quase todas as festas. Pequenas ajudas. Nunca damos muito também, para não acostumar demais [risadas]. Eu colaboro em outras coisas. Por exemplo, levá-las de um lado para outro, ajudar numa despesa. Quando dona Amélia vai à Casa das Minas, faço questão de levar e trazer no meu carro. Eu levo muito dona Celeste para a casa dela. Eu colaboro com transporte e outras coisas. Às vezes, elas me pedem algumas coisas específicas. Para ajudar a conseguir uma fruta, por exemplo, no arrambã, que precisa de muitas frutas; então eu vou ajudar, levo-as e depois trago. Colaboro numa posição muito subalterna, sobretudo como motorista. No começo, eu era o fotógrafo. Agora, quando tem toques, às vezes, me disponho a tocar o tambor pequeno quando falta um tocador. Há a observação daquele tabu de não ter relações sexuais três dias antes.

V.G.S. Mas, aí elas pedem para você tocar e te avisam?

S.F. Eu é que já me preparo antes e fico à disposição. Eu vou de branco e, se precisar de um tocador, bato o tambor pequeno. Tem as proibições de comidas também. Caranguejo é proibido. Eu adorava caranguejo. Eu comia caranguejo escondido. Todo domingo, eu ia à praia comer caranguejo. Até o dia em que o médico me proibiu [risadas]. Na Casa das Minas é tabu. E tem outros. Quando vamos a um tambor de choro na Casa de Nagô tem que vir se limpar na Casa das Minas. Tem algumas coisas assim. E tem que comer comida de obrigação. Tem que assistir o jônu, o nadopé. Tem as partes privadas antes e depois das festas, e participamos delas sempre que somos convidados. Somos avisados e devemos ir. Não ir é malvisto, é uma coisa fora da etiqueta. 
V.G.S. E isso tem um impacto emocional sobre você. Por exemplo, de não comer caranguejo. Porque você tem uma formação mais materialista, não?

S.F. Não. Eu não tenho formação materialista. A minha família sempre foi muito religiosa.

V.G.S. Quero dizer, de formação intelectual marxista.

S.F. Não, eu nunca fui muito materialista. Fui cristão durante muito tempo. Eu não tenho uma tradição de formação materialista. Sempre fui crente. Durante minha graduação na universidade eu era profundamente católico. Eu queria voltar para o mosteiro.

V.G.S. Você não abandonou o seminário por uma oposição à teologia?

S.F. Não. Eu acho que muitas vezes na Casa das Minas eu me sinto como se estivesse dentro de um mosteiro. Então, acho que é uma continuação.

V.G.S. Isso para você é uma coisa tranquila?

S.F. Muito tranquila. Eu não tenho nenhum conflito em relação a isso. Eu passei de uma coisa para a outra, e como essa religião aceita as duas... Mas eu deixei o catolicismo depois que me casei. Mas fui passando com muita naturalidade do catolicismo para a religião afro e agora estou voltando um pouco a certas práticas [risadas] porque muitas vezes temos que ir à missa na Casa das Minas. Então, de tanto ir à missa e assistir ladainha estou voltando a ser católico [risadas]. E eu tinha muita implicância com o catolicismo depois de certa data, de uma certa parte. Mas gostava profundamente da liturgia. E justamente a liturgia é o que mais me atrai na Casa das Minas.

V.G.S. Como você avalia a participação religiosa do pesquisador. Ajuda? Atrapalha?

S.F. Acho que ajuda. É indispensável. Se o pesquisador vai estudar religião, ele tem que estar mordido pela religião.

V.G.S. Mas isso deve ir até a conversão ou não?

S.F. Temos que pesquisar uma coisa de que gostamos, entende? Porque pesquisa é uma coisa chata e difícil, e você tem que gostar, seja do carnaval, do boi, do tambor de crioula. Para você fazer um trabalho, seja com índios, com campesinato, você tem que gostar daquela temática. Então, o fato de você gostar implica virar um pouco nativo. Você não pode fazer um trabalho de pesquisa sem virar nativo. É aquela história de Evan-Pritchard (2005): quando eu estava entre os Azande, eu não podia deixar de acreditar em feitiçaria. Porque era impossível viver entre eles sem 
acreditar em feitiçaria. Normalmente quando você entra em um campo assim... eu não digo que aceite tudo. Tem certas coisas que tenho certas resistências. Por exemplo, aceitar banhos. Foi uma das coisas com relação às quais que tive muita resistência. Hoje em dia faço com a maior naturalidade. No começo não aceitava que o banho tivesse um certo significado [risadas]. Hoje tomo com a maior naturalidade.

V.G.S. Mas você compartilha um certo sentido que elas atribuem às coisas? Por exemplo, quando elas dizem assim: "Aqui só entra quem começa a dançar e o vodum chega e diz o próprio nome".

S.F. Ah, eu concordo com elas.

V.G.S. Isso ajudou a fazer a pesquisa e impregnou a tua interpretação?

S.F. Acho que sim. Acredito que os voduns são entidades sobrenaturais. Não é uma mera criação delas. Pode até ser um sonho, um imaginário. Mas da mesma forma que os católicos acreditam que a hóstia é o corpo de Cristo, eu não discuto esse problema. Não digo que faço teologia; não sou teólogo. Mas é muito próximo da teologia o trabalho que fazemos, a antropologia da religião. Eu lamento não ser teólogo. Se eu fosse teólogo de formação, acho que faria um trabalho teológico mais bem feito [risadas]. Então, por isso que não faço teologia. Há no Maranhão problemas de preconceito na academia. Tem muita dificuldade de ser aceito. Mas, sobretudo no tambor de mina tudo é muito discreto e você não tem que dar provas públicas de nada, não tem que mostrar para ninguém. Tudo se passa em seu íntimo. Às vezes, alguns alunos perguntam, e eu respondo com Evans-Pritchard: "O Evans-Pritchard disse que não gostava de boi, mas quando foi para os Nuer teve que estudar boi porque era o que era importante para os Nuer. Ele não gostava de feitiçaria, não acreditava; mas entre os Azande, ele acreditava". Mas é claro que se saímos daquele meio durante muito tempo, vamos nos afastando daquelas práticas. Mas eu moro aqui em São Luís e estou sempre naquele meio. Eu vou a todas as festas da Casa das Minas. Porque eu gosto, entende?

V.G.S. Não necessariamente para pesquisar, porque as informações você já tem quase todas.

S.F. Não. Dona Celeste faz questão de dizer que ela nunca disse tudo. Sempre estou aprendendo um pouco. Mesmo sobre a etnografia, estou sempre aprendendo coisas que posso aproveitar de outras formas. É um campo muito vasto, com possibilidade de outros trabalhos. Eu já não sou jovem assim, me aproximei da Casa já mais maduro e não pretendo fazer muitos outros voos. Talvez escreva uma ou outra coisa fora desse assunto. Mas pretendo continuar trabalhando nele. É como um poço sem fim, tem muitos tesouros lá que continuo descobrindo e utilizando profissionalmente. 
V.G.S. E essa questão da tradição. Muitas vezes os antropólogos a inventam?

S.F. Eu não concordo... É claro que aquilo que escrevemos vai sendo canonizado. $E$, às vezes, canonizamos erradamente. Depois que descobrimos que está errado, dez, 20 anos depois, e aquilo já virou prática porque outras pessoas foram lendo e foram aceitando como certo. Mas, para isso, me volto a Max Weber. O conhecimento científico é um vir a ser que se renova e coloca sempre novas questões. Não é uma coisa acabada. Então, o que fazemos é datado. Quando eu publicar outro trabalho ele terá outra data. Por exemplo, vou publicar a segunda edição do meu livro, o Querebentã, que vai ser revisto e vai ter mais umas 20 notas. Algumas coisas que já passaram, mas deixo assim mesmo. Algumas correções e alterações eu fiz, mas o essencial eu mantive. Gosto muito desse livro e acho que é aquilo mesmo.

V.G.S. Mas quando você diz que o intelectual também pode criar uma tradição, você pensa em quem? Por exemplo, o Fanti-Achanti não é o resultado de uma tradição inventada por intelectuais?

S.F. Não. Sabemos que Arthur Ramos fala em Fanti-Achanti. E sabemos que Euclides é uma pessoa que gosta de ler. Acho que foi Euclides quem inventou a Casa de FantiAchanti inspirado em coisas que ele ouviu, viu e leu. Ele inventou a tradição dele. Inclusive, ele não conheceu Arthur Ramos, não foi amigo dele. Não foi Artur Ramos que inventou a Casa de Fanti-Achanti. Arthur Ramos (1937) em Culturas negras no Novo Mundo fala da cultura fanti-achanti, mas a Casa de Fanti-Achanti é criação de Euclides, baseado nas coisas que ele ouviu do passado e que ele leu; ele teve uma inspiração intelectual e juntou as duas coisas. A Casa das Minas também foi criada ao longo dos tempos com o aporte de intelectuais do passado. Nunes Pereira ajudou, e, antes dele, outros ajudaram, entende? Pouco antes dele, houve Edmundo Correia Lopes em I938 ou I940. E Edmundo já menciona, e Nunes Pereira também, Alvaro de las Casas, que era um escritor espanhol. Esses são os que conhecemos da literatura em I937, I938. Mas seguramente houve figuras, provavelmente da maçonaria ou da intelectualidade maranhense, cujos nomes não ficaram registrados, e gente de lá de dentro mesmo, por exemplo da família Nazaré, que é a família de Alcione Nazaré, que eram muito de dentro da Casa, e havia sobretudo pessoas que ajudavam. Eu tenho impressão de que eles sempre se cercaram de intelectuais, intelectuais num sentido amplo, não intelectuais eruditos, mas pessoas que sabiam escrever e foram traduzindo essa tradição. Agora, com aquele discurso sempre de que era uma coisa deixada pelos africanos [...] De fato, elas continuam muitas práticas antigas. Não aceito a observação de que a tradição é uma invenção dos intelectuais. Essa tradição é uma criação dos fundadores junto com o meio da época, com as forças do meio com que eles se aliaram. Eles se aliaram a figuras, à maçonaria, a médicos, professores, advogados que os ajudaram e eles criaram essa tradição e continuam a criá-la. Os chamados ogãs, aqui, não têm essa tradição externa, oficial; as coisas aqui são muito escondidas, mas sempre houve. 
V.G.S. Em São Luís muitos pais de santo escrevem livros, como o Euclides e o Jorge.

S.F. Aqui tinha um autor (esqueci agora o seu nome) que escreveu a História do espiritismo no Maranhão, em I955. Ele pesquisou muito a Casa das Minas. Havia essa tradição de escrever. E Euclides, Jorge e Sebastião do Coroado também escreveram. Jorge já tem um livro pronto. Euclides já tem três. Está no quarto e quer escrever um comigo sobre a história da mina no Maranhão. São Luís tem a tradição de ser uma cidade intelectual, culta, e mesmo as pessoas de origem simples gostam de ler e escrever. Dona Deni, por exemplo, lê muito sobre espiritismo, sobre bíblia. Hoje em dia ela lê menos, tem dificuldades, mas ela é uma pessoa letrada. Formou-se como normalista, se não me engano.

V.G.S. Talvez escrever sobre a religião seja uma maneira de estabelecer uma liderança. Aqui as lideranças, Euclides, Jorge, são pessoas que escrevem.

S.F. Isso é muito contestável porque existem outras formas de lideranças. Existem outros chefes muito importantes na religião de um modo geral, que nunca escreveram nada e acho que não vão escrever, como Elzita, Zé Negreiros e inúmeros outros. Agora, por aqui, alguns gostam de escrever. Não só aqui como no Pará também.

V.G.S. Mas Euclides e Jorge têm uma projeção grande.

S.F. Mas acho que não é pela escrita. É muito mais pela coreografia. Euclides é um grande coreógrafo. Um Nijinsky. E Jorge é um Joãosinho Trinta. As festas deles são belíssimas. As pessoas vão lá por isso. Dona Celeste não escreve nada, mas faz uma festa do divino maravilhosa. Todo mundo vai e fica encantado. Ela sabe organizar uma festa do divino em que ela recebe pessoas desde a alta sociedade até as mais simples. Acho que é muito mais pela prática do que pela escrita, sobretudo nos casos de Euclides e Jorge, cujos livros são conhecidos mais pelos intelectuais do que pelo povo. As pessoas de cor os procuram não porque escreveram um livro, mas porque a Casa deles é bonita. Faz festas muito bonitas. O cântico e a dança são bonitos.

V.G.S. Eles se assentam pelo livro mais no meio intelectual... Agora o tambor da Casa das Minas também é concorrido?

S.F. Não. Poucas pessoas vão à Casa das Minas. As festas na Casa de Nagô são muito maiores. Quase ninguém sabe ou conhece o calendário da Casa das Minas. Não é divulgado.

V.G.S. Quando você foi escrever o texto da etnografia, que dificuldades você teve para fazer esta passagem da observação para a descrição? 
S.F. Eu faço um diálogo junto com elas, entende? Meu texto é construído em cima da fala delas. Dona Celeste diz isso, dona Deni diz isso. Mas dei uma organização a esses dados. Fichte deu outra. Ele, por exemplo, indica: "Fulano de tal no dia tal disse isso". Precisamente com o dia e o nome da pessoa. Eu não sou tão rigoroso assim. Mas talvez a repetitividade e algumas falhas de meu livro decorram disso: fiz o texto muito em cima da fala delas. Eu ia arrumando a fala delas e ia encaixando. De fato, sou eu que assino o livro; na etnografia clássica sou eu que assino. Não faço como o First Time, de Richard Price (1983). Mas elas se reconhecem ali. No caso de coisas em que eu não poderia dizer alguma coisa, eu usei o recurso de dizer que foi outrem quem me disse e mesmo quando não é para dizer quem me disse, eu deixo a informação genérica para evitar que o meu texto crie problemas porque sei que vai ser lido aqui... Não procurei uma teoria para pendurar meus dados, tentei amarrar os dados alinhavando as falas das vodunsi da Casa com um pouco das teorias que julgava pertinentes. Creio que, se eu tivesse que escolher uma teoria, eu seria estrutural-funcionalista [risadas] sobretudo no Querebentã. No outro [Repensando o sincretismo], eu não sei. Tem hora que o texto sai, flui. Tem horas que fica amarrado. O texto do doutoramento já foi mais fácil de escrever. Foi mais difícil conceber a organização, o trabalho.

V.G.S. Você atribui a quê? À experiência?

S.F. À experiência, acho. Mas gosto muito mais do primeiro livro, que para mim foi uma coisa de maior importância, embora ele tenha muitas falhas, sobretudo no texto. O segundo foi mais obrigação. Mas gosto também dele.

Recebido em Io/4/2019 | Aprovado em I3/5/2019

Vagner Gonçalves da Silva é antropólogo e professor da Universidade de São Paulo. Desenvolve pesquisas na área das populações afro-brasileiras, enfocando temas como religiosidade (candomblé, umbanda, neopentecostalismo, intolerância religiosa), relações entre religião e cultura brasileira (festas populares, música, capoeira, literatura, cinema etc.) e artes afro-brasileiras. Publicou e editou, entre outras obras, Candomblé e umbanda; Orixás da metrópole; O antropólogo e sua magia; Intolerância religiosa; Memória afro-brasileira (coleção em três volumes) e Exu - Guardião da Casa do Futuro. 


\section{REFERÊNCIAS BIBLIOGRÁFICAS}

Bastide, Roger. (I97I). As religiões qfricanas no Brasil. São Paulo, Livraria Editora Pioneira.

Eduardo, Octávio da Costa. (1948). The negro in Northern Brazil, a study in acculturation. New York: J.J. Augustin Publisher.

Evans-Pritchard, E.E. (2005). Bruxaria, oráculos e magia entre os Azande. Rio de Janeiro: Zahar.

Ferretti, Sergio. (2009). Querebentan de Zomadonu: etnografia da Casa das Minas. 3 ed. revisada e atualizada. Rio de Janeiro: Pallas.

Ferretti, Sergio. (1996). Querebentan de Zomadonu: etnografia da Casa das Minas do Maranhão. 2 ed. revista e atualizada. São Luís: Editora da Universidade do Maranhão.

Ferrretti, Sergio. (1995). Repensando o sincretismo: estudo sobre a Casa das Minas. São Paulo/São Luís: Edusp/Fapema.

Ferretti, Sergio. (1985). Querebentan de Zomadonu: etnografia da Casa das Minas. São Luís: Editora da Universidade do Maranhão.

Ferretti, Sergio. (1983). Querebentan de Zomadonu: um estudo antropológico da religião da Casa das Minas. Dissertação de Mestrado. PMCS/Universidade Federal do Rio Grande do Norte.

Ferretti, S.F.; Cécio, V.; Moraes, J.; Lima, R. (orgs.). (I98I). Tambor de crioula. Rio de Janeiro: Instituto Nacional do Folclore/ Fundação Nacional de Arte.

Ferretti, S.F.; Valdelino, C; Moraes, J. (orgs). (I978). Dança do lelê. Rio de Janeiro: Ministério da Educação e Cultura/Fundação Nacional de Arte/Campanha de Defesa do Folclore Brasileiro.

Ferreti, S.F; Soares, D. J.; Silva, M. J. (orgs.). (1977). A dança do lelê na cidade de Rosário no Maranhão. São Luís: Func/Sioge.

Fichte, Hubert. (20I7). Explosão - romance da etnologia. Tradução de Marcelo Backes. São Paulo: Hedra.

Fichte, Hubert. (1987). Etnopoesia - antropologia poética das religiões afro-americanas. São Paulo: Brasiliense.

Griaule, Marcel. (1997). Dieu d'eau, entretiens avec Ogotemmêli. Paris: Fayard.

Pereira, Manuel Nunes. (1979). A Casa das Minas: culto dos voduns jeje no Maranhão. 2 ed. revista e ampliada. Petrópolis: Vozes. 
Pereira, Manuel Nunes. (1947). A Casa das Minas: contribuição ao estudo das sobrevivências daomeianas no Brasil. Introdução de Arthur Ramos. Rio de Janeiro: Sociedade Brasileira de Antropologia e Etnologia.

Price, Richard. (1983). First time - the historical vision of an AfroAmerican people. Baltimore: The John Hopkins University Press.

Ramos, Arthur. (1937). Culturas negras no Novo Mundo. Rio de Janeiro: Civilização Brasileira.

Reis, Waldemiro E. dos. (s/d). Espiritismo e mediunidade no Maranhão. São Luís: s/informação.

Silva, Vagner Gonçalves da. (2000). O antropólogo e sua magia. São Paulo: Edusp.

Ziegler, Jean. (1977). Os vivos e a morte: uma sociologia da morte no Ocidente e na Diáspora. Rio de Janeiro: Zahar Editores. 
Palavras-chave

Religiões afro-brasileiras;

etnografia;

Casa das Minas;

São Luís do Maranhão;

Sergio Ferretti.

Keywords

Afro-Brazilian religions;

ethnography;

Casa das Minas;

São Luís do Maranhão;

Sergio Ferretti.

\section{MEMÓRIAS E EXPERIÊNCIAS DE PESQUISA NA} CASA DAS MINAS DE SÃO LUÍS DO MARANHÃO: ENTREVISTA COM SERGIO FERRETTI

\section{Resumo}

A entrevista com Sergio Ferretti foi realizada no contexto da pesquisa de doutoramento de Vagner Silva sobre o trabalho de campo e a produção de textos etnográficos na área dos estudos sobre as religiões afro-brasileiras. Com o tom informal de uma conversa entre colegas, ambos especialistas no assunto enfocado, Ferretti, conduzido pelas perguntas de Silva, discorre sobre seu longo e denso contato de pesquisa com a Casa das Minas de São Luís do Maranhão.

\section{MEMORIES AND RESEARCH EXPERIENCES AT THE} CASA DAS MINAS OF SÃO LUÍS DO MARANHÃO:

\section{AN INTERVIEW WITH SERGIO FERRETTI}

\section{Abstract}

The interview with Sergio Ferretti was carried out in the context of Vagner Silva's doctoral research on fieldwork and the production of ethnographic texts on Afro-Brazilian religions. With the informal tone of a conversation between colleagues, both experts on the subject, Ferretti, led by Silva's questions, discusses his long and dense research contact with the Casa das Minas of São Luís do Maranhão. 